Document downloaded from:

http://hdl.handle.net/10251/82715

This paper must be cited as:

Pedro Monzonis, M.; Ferrer Polo, FJ.; Solera Solera, A.; Estrela Monreal, T.; Paredes Arquiola, J. (2015). Key Issues for Determining the Exploitable Water Resources in a Mediterranean River Basin. Science of the Total Environment. 503-504:319-328. doi:10.1016/j.scitotenv.2014.07.042.

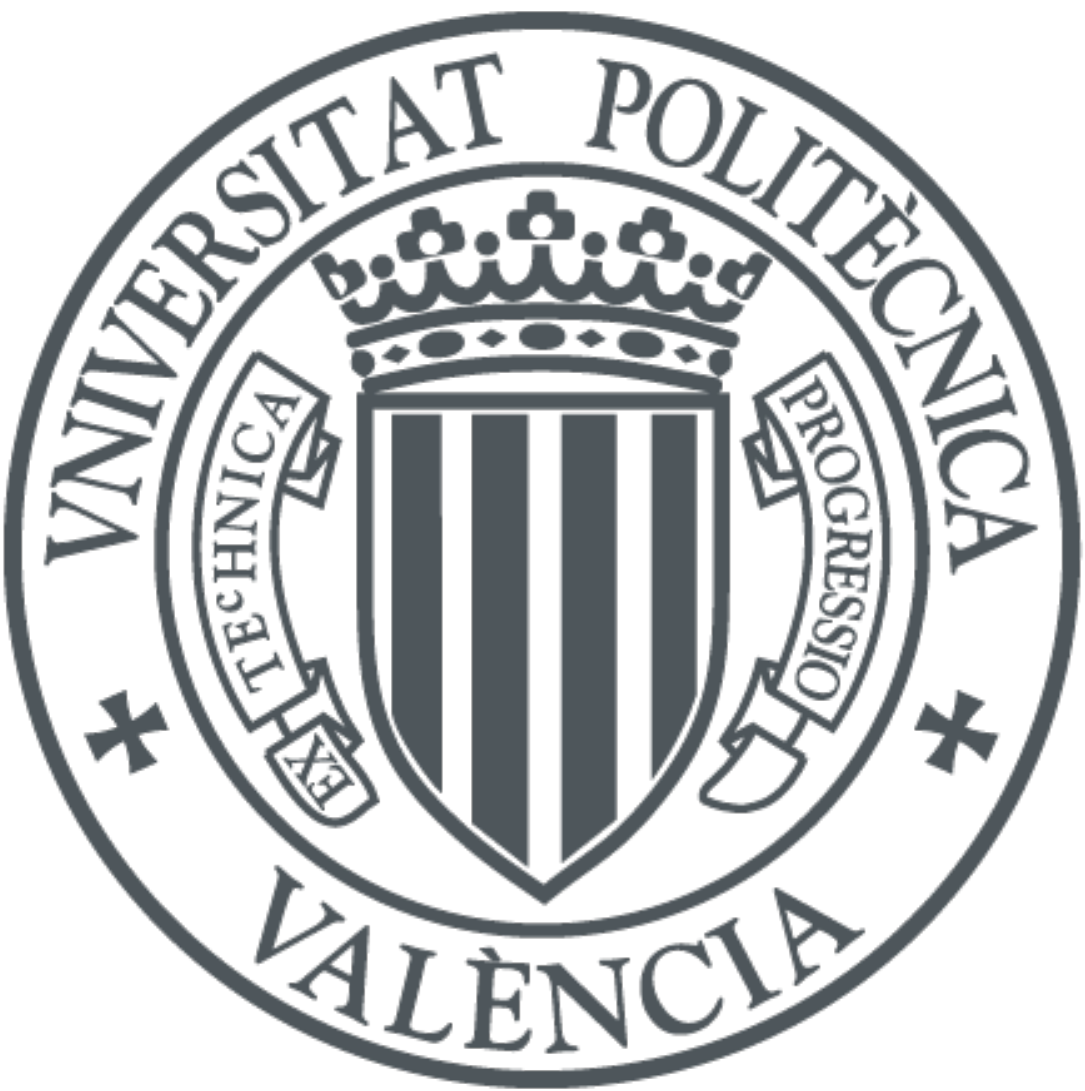

The final publication is available at

http://dx.doi.org/10.1016/j.scitotenv.2014.07.042

Copyright ELSEVIER SCIENCE BV

Additional Information 


\title{
Key Issues for Determining the Exploitable Water Resources in a Mediterranean River Basin
}

\author{
María Pedro-Monzonís ${ }^{1 *}$, Javier Ferrer ${ }^{2}$, Abel Solera ${ }^{1}$, Teodoro Estrela $^{2}$, Javier Paredes-Arquiola ${ }^{1}$ \\ 1 Research Institute of Water and Environmental Engineering (IIAMA), Universitat Politècnica de València, Camino de Vera S/N, 46022 \\ Valencia (Spain) \\ 2 Confederación Hidrográfica del Júcar (CHJ) Júcar River Basin Authority, Avda. Blasco Ibáñez 48, 46010 Valencia (Spain) \\ *mapedmon@upv.es
}

\begin{abstract}
One of the major difficulties in water planning is to determine the water availability in a water resource system in order to distribute water sustainably. In this paper, we analyse the key issues for determining the exploitable water resources as an indicator of water availability in a Mediterranean river basin. Historically, these territories are characterised by heavily regulated water resources and the extensive use of unconventional resources (desalination and wastewater reuse); hence, emulating the hydrological cycle is not enough. This analysis considers the Jucar River Basin as a case study. We have analysed the different possible combinations between the streamflow time series, the length of the simulation period and the reliability criteria. As expected, the results show a wide dispersion, proving the great influence of the reliability criteria used for the quantification and localization of the exploitable water resources in the system. Therefore, it is considered risky to provide a single value to represent the water availability in the Jucar water resources system. In this sense, it is necessary that policymakers and stakeholders make a decision about the methodology used to determine the exploitable water resources in a river basin.
\end{abstract}

Keywords: water availability, Jucar River Basin, exploitable water resource, water accounts, water resources systems

\section{Introduction}

The importance of water to society is broadly recognized. As noted in the Blueprint to safeguard Europe's water resources (EC, 2012), we need to know how much water is available in order to distribute it sustainably. One of the major difficulties lies in computing water resources, as they depend on several factors, some of which are difficult to quantify. Water resources are presented in random order in the sense that they cannot be fully explained by a reduced number of physical causal factors (Marco, 1993). To assess these resources, water accounts, as defined by United Nations, have become a very powerful tool for improving water management as they provide a method of organizing and presenting information relating to the physical volumes of water in the environment, the water supply and the economy (Vardon et al., 2007). The main purpose of the System of Environmental-Economic Accounting for Water (SEEAW) (UNSD, 2012) is to provide a standard approach and therefore the possibility to compare results among different areas (Evaluación de Recursos Naturales, 2013).

Many studies have used the concept of water availability in different senses: the European Environmental Agency (EEA) (2009) considers precipitation, river flows and the storage of water in snow and glaciers as a measure of the availability of freshwater resources, while other authors (Lorenzo-Lacruz et al., 2010; PérezBlanco and Gómez, submitted for publication) have estimated water availability by employing drought indexes. Furthermore, Lange et al. (2007) and Sun et al. (2002, 2005, 2006) consider that regional water resource availability can be well described by water yield, defined as the difference between received precipitation and evapotranspiration, and representing the maximum water availability for natural ecosystems and human society (Lu et al., 2013). 
However, not all natural resources can - or should - be considered as supplies that can be used to meet water demand (MMA, 2000). It is noteworthy that some external constraints (environmental, socio-economic or geopolitical) exist in the system itself that limit potential water use. There are also other technical restrictions that limit the use of resources. In this sense, the available resource is defined as a resource that depends on the characteristics of natural resources, external constraints and technical limitations (MMA, 2000). In other words, the concept of water availability is related to the ability of a country to mobilize water (UNSD, 2012). This concept is important because knowing the available resources of a basin will aid the planner to place a value on its growth potential in the exploitation of the system. In the same way, AQUASTAT (FAO's global water information system) has suggested the use of an indicator of exploitable water resources to quantify water availability. This indicator is defined as the part of the water resources considered to be available for development under specific technical, economic and environmental conditions (UNSD, 2012). Unlike natural resources, whose meaning is widely accepted, there is disagreement as regards the best process for calculating exploitable water resources (MMA, 2000; UNSD, 2012). This concept is extremely important in Mediterranean countries where precipitation is scarce, evapotranspiration is intense and there is marked seasonality of the rainfall, often causing drought periods during summer (Delgado et al., 2010).

The aim of this paper is to design a scheme of conditions for determining the exploitable water resources in a Mediterranean basin. Historically, Mediterranean countries have suffered important drought periods that have caused severe impacts. Water scarcity and the frequent drought periods explain, in part, the ancient building tradition of hydraulic works (Estrela and Vargas, 2012). These territories are characterised by heavily regulated water resources and the extensive use of unconventional resources, such as desalination and wastewater reuse (Vargas-Amelín and Pindado, 2013), which is the main reason why emulating the hydrological cycle is not enough. This approach is completed by the analysis of the Jucar River Basin (Spain), which, as in other many Mediterranean basins, is currently water-stressed. To achieve this goal, the study draws on the SIMGES simulation model of water resources (Andreu et al., 1996) from the Decision Support System (DSS) AQUATOOL. As expected, the results are very different, proving the need for a standardized methodology to determine the exploitable water resources in a basin.

\section{Materials and methods}

Water resources systems analysis comprises all of the necessary elements needed to describe a river basin. These elements represent the natural resources system, the socio-economic system and the administrative and institutional system (Loucks and van Beek, 2005) and include factors such as water resources, water demands, infrastructures, environmental requirements, reservoir operating rules, etc. In this sense, water resources management can be performed in different ways, among which the use of simulation models is the most reliable method. Simulation models provide information that can help improve water resources system management and planning processes (Sulis and Sechi, 2013). An extended state-of-the-art review on simulation and optimization modelling approaches has been provided by Rani and Moreira (2010). Moreover, as noted by Chavez-Jimenez et al. (2013), a system is the unit through which the exploitation of water resources may be modelled as a set of dynamically related elements that perform an activity to meet the objective of satisfying demand.

Therefore, to assess the water availability in a water resources system, it is necessary to use simulation models (see figure 1). The results obtained with the simulation models can be grouped in a water balance that represents an accounting of the inflow, outflow and storage of water during the simulation period. One such result is the time-dependent water supply. Once the time series of water supplies has been determined, it can be compared with the water demand in order to obtain the system's reliability. The indicator of exploitable 
water resources is linked to the reliability criteria. Therefore, if water managers accept a less severe level of reliability, it will be possible to address a larger demand than if the level were more severe. Once the reliability criteria have been selected, the exploitable water resources are obtained as the maximum demand that can be served.

Figure 1. General scheme to obtain the exploitable water resources in a river basin

\subsection{Water Resources Systems Analysis and Water Resources Management Models}

Water resources systems analysis consists of the analytical study of the water resources in a river basin in order to help decision makers to identify and choose one alternative from other possible ones. Quantitative and holistic knowledge of basin hydrology becomes essential as water management needs become increasingly complex (Masih et al., 2009). Molle et al. (2004) concluded that as water demands increase and more water is allocated to different uses, the management of water resources becomes increasingly complex due to a large number of interacting factors. The greater the complexity of the system is, the greater the need for a water resource management model in order to identify the system's water availability.

The planning and management of a water resources system may be simulated using SIMGES, a management simulation model in the generalized tool AQUATOOL (Andreu et al., 1996). AQUATOOL is a user-friendly DSS widely employed in Spanish water basins, as well as in other countries (e.g., Chile, Italy, Morocco, etc.). This DSS allows the definition of monthly conjunctive-use management models at the basin scale, and, as noted by Pulido-Velazquez et al. (2011), permits the simulation of management alternatives for complex large-scale systems over long time horizons. The SIMGES model can simulate the water resources system, on a monthly time scale, by a simple flow balance in a flow network in order to find a flow solution compatible with the defined constraints. Moreover, the SIMGES model allows us to define operating rules to reproduce sourcedemand interactions that can help improve integrated river basin management.

\subsection{Components of a water resources system}

Simulation models are simplified mathematical representations of water allocations over a period of time under given boundary conditions. Thus, in order to define the main elements to be included, we must distinguish between natural elements in the river basin and anthropogenic elements that produce alterations in river flows.

\subsubsection{Natural elements}

Among natural elements we consider rivers, natural streamflows and aquifers, as well as their interactions. Natural streamflows represent the flows of a particular area of the basin corresponding to its drain point and are the most important elements for river basin management, as they represent the flows that are to be managed (Solera et al., 2010a). The random nature of streamflows requires a hypothesis to be established regarding the best way to obtain streamflow data. In this sense, it is common to use time series of naturalized streamflows, which are characterized by a number of statistical properties such as bias, seasonality and spatial and temporal correlation. Other options are to use time series obtained with a rainfall-runoff model or resorting to the use of stochastic models. In water planning, the usual practice is to analyse the system's operation over a long period of time under different hydrological conditions. However, because planning is performed for future needs, historical streamflow data will not be repeated, so it is justifiable to use statistical models for the generation of future scenarios of varying lengths (Solera et al., 2010b). 
To estimate water availability, it is necessary to accept a hypothesis about how these natural streamflows will be presented, which will largely determine the results and conclusions. This paper proposes a twofold approach: a first analysis using a time series of naturalized streamflows and a second analysis employing synthetic streamflows. In the second case, a large number of stochastic time series equivalents to the naturalized ones are obtained with a stochastic generation model and then used as an input to the deterministic simulation model. In this way, it will be possible to evaluate the statistical properties of the considered options (Loucks and van Beek, 2005). The generation method employed in this study is the multivariate ARMA model (Box and Jenkins, 1976).

\subsubsection{Infrastructures}

We consider infrastructures as all of the elements that allow water managers to operate or control the flow of water in the river basin. The most important elements are reservoirs, pumping wells and channels. As all models produce simplified representations of real-world systems (Sulis and Sechi, 2013), they must include the system's main features, such as rivers, reservoirs, aquifers, existing uses represented by the demand centres, hydraulic connections, the possibility of using returns and other unconventional resources, and the consideration or not of environmental constraints or operating rules.

To analyse water availability, a very important aspect to consider is the capacity to mobilize resources in the system. Therefore, we need to consider the existing level of technology at each moment in order to distinguish between conventional and unconventional resources. We define as conventional resources the amount of water regulated in reservoirs and groundwater pumping. Unconventional resources often include resources from direct reuse and desalination, but on account of being associated with the existing technology, these resources are a dynamic concept that varies with time. Moreover, the use of the returns of previous supplies represents a double use of water resources. This fact is essential in Mediterranean countries, where the majority of the available resources are used for irrigation, resulting in large volumes of returns. Equally important is the management of the operating system, defined as a set of operating rules for the water infrastructure system, representing another of the key aspects in the water availability. In this way, optimal water resource management can increase the availability of the system, while a deficient management inevitably reduces it.

\subsubsection{Demands}

The purpose of water resources management is to satisfy a set of water uses. We can distinguish among several types of uses, each of which requires a certain amount of water at a certain time and place (Solera et al., 2010a). These uses may refer to environmental requirements, agricultural and urban demands, and hydroelectric and recreational uses.

Because streamflows are scattered throughout the basin, the water availability will vary depending on where water is needed. As noted by Bangash et al. (2012) water is typically allocated according to historical, institutional, political, legal, and social traditions and conditions. Likewise, if an allocation of water is assigned in a part of the basin, this allocation will modify the water availability in the rest of the basin. Furthermore, due to the seasonal variability of water resources and the limited capacity of system regulation, the allocation will vary if the demands are concentrated in different seasons.

Despite the regulation of the water resources system, we cannot be confident that all demands have satisfied their supply because it depends on the random nature of streamflows. Reliability measures the frequency or probability of success of the system by simply counting the number of days that the system was in a "satisfactory state" compared to the total simulation length (Asefa et al., 2014; Hashimoto et al., 1982); this 
method is traditionally used to judge whether the adoption of long-term corrective actions is necessary. Thus, having high levels of reliability means having less water resource availability and vice versa.

Two reliability criteria have been selected in order to assess the availability of water resources. The first criterion is the one established in the Spanish Statement of Water Planning (IPH, 2008), and the second is the efficiency indicators defined by Martín-Carrasco and Garrote (2007). The IPH (2008) indicates that for the purposes of resource allocation and reservation, urban demand is considered satisfied when the deficit in one month does not exceed $10 \%$ of the corresponding monthly demand and when in 10 consecutive years, the sum of deficits is less than $8 \%$ of the annual demand. Similarly, for the purposes of resource allocation and reservation, agrarian demand is considered satisfied when the deficit in one year does not exceed $50 \%$ of the corresponding demand; for two consecutive years, the sum of deficit does not exceed $75 \%$ of annual demand; and in ten consecutive years, the sum of deficit does not exceed $100 \%$ of the annual demand. On the other hand, the efficiency indicators used are (1) the demand-satisfaction index $\left(I_{1}\right)$, which evaluates the capability of the system to meet demand and (2) the demand-reliability index $\left(I_{2}\right)$, which assesses the reliability of the system to satisfy demand. The use of the efficiency indicators requires grouping the demands across several classes depending on their respective use of water. As noted in Chavez-Jimenez et al. (2013), the behaviour of the system is characterized according to the indicators $I_{1}$ and $I_{2}$. According to the values of $I_{1}$ and $I_{2}$, we can determine the intensity of the problems that can occur in the system (see Figure 2). More detailed information about the use of these indicators can be found in Martín-Carrasco and Garrote (2007).

Figure 2. Demand-reliability curve (DR curve) (left) and diagnosis of severity of water scarcity problems according to indicator values $I_{1}$ and $I_{2}$ (right) (Chavez-Jimenez et al., 2013).

\subsection{Calculation process for determining the exploitable water resources}

To measure water availability, the indicator of exploitable water resources will be used, which is determined as the maximum demand that can be served in a water exploitation system while complying with the reliability criteria established by law.

The steps used to obtain this indicator are as follows: (1) select a hypothesis about how to obtain the natural streamflows in the simulation model; (2) select the reliability criteria that allow us to consider the supply to be satisfied; (3) select all possible places in the system where new water allocations are likely to be required, apart from the existing demand centres; (4) define the type of use in these new places (urban use requires a uniform year-round supply, and agrarian use concentrates its supply during the harvest months) with a demand element in the simulation model; (5) using an iterative process, analyse the possibility of increasing a single demand in each step while considering the other demands as zero, execute the simulation model, and check if the adopted reliability criteria are met at each step; and (6) the final result is achieved when the maximum demand is obtained while fulfilling the required reliability criteria.

As explained in step (5) (see figure 3), the exploitable water resources are determined through an iterative process in which the model SIMGES is run with different water demand values, and the reliability criterion is analysed to compare the supply and demands. The monthly values for each demand are obtained by multiplying a definite temporal pattern (different for urban and agricultural demands) by a changing value (X). In the first iteration, $X$ has to be a very high figure. If the reliability criterion is met when SIMGES is run, we accept the demand quantity as the exploitable water resources. However, if the reliability criterion is not met, a new demand is obtained using the bisection method until the highest demand that meets the reliability criterion is 
found, accepting an absolute error (E) of $0.05 \mathrm{hm}^{3} /$ month. In the case study, the initial value for $X$ was 200 $\mathrm{hm}^{3} /$ month, and 14 iterations were required to calculate the exploitable water resources of the system.

The results depend on the geographical area in which the demands are to be increased, either at the head of the system, in the middle section or at the mouth area, because any alteration of the system will affect the uses located downstream of such an alteration. Similarly, the timing of the use will also influence these results because it will be dictated by the type of use for which the resource is intended.

Figure 3. Iterative process

\section{Case study: The Jucar River Basin}

\subsection{Characterization of the study area}

The Jucar River Basin is located in the eastern part of the Iberian Peninsula in Spain (see figure 4). This basin is the main principal water exploitation system of the 9 in the Jucar River Basin District, thus giving it its name. The Jucar River has a length of $497.5 \mathrm{~km}$, traversing the provinces of Teruel, Cuenca, Albacete and Valencia, with its mouth at the Mediterranean Sea. Additionally, this water exploitation system includes the area and services provided by the Jucar-Turia Channel and the littoral sub-basins between the Albufera Lake and a location approximately 10 kilometres south from the mouth of the river. It is the most extensive system $\left(22,261 \mathrm{~km}^{2}\right)$ and provides the greatest amount of water resources in the Jucar River Basin Agency. A brief description of the study area and key issues is presented below; details can be found in Ferrer et al. (2012).

Figure 4. Location of the Jucar River Basin in the Iberian Peninsula

Physically, the Jucar River basin is described as an interior mountainous zone, with spots at high altitude and a coastal zone composed of plains. This means that $25 \%$ of the basin is at elevations over $1,000 \mathrm{~m}$, while the remaining area is below this level ( $27 \%$ corresponds to plains below the Central plateau and $48 \%$ to plains on the Central plateau). Precipitation exhibits a high spatial variability $(450 \mathrm{~mm} / \mathrm{year}$ in the low basin and $630 \mathrm{~mm} /$ year in the north of the basin). The average precipitation is $510 \mathrm{~mm} /$ year, and the average temperature is $13.6^{\circ} \mathrm{C}$. The average natural water resources reach $1,279 \mathrm{hm}^{3} /$ year, representing the top limit of the renewable resources of the basin. The total population that depends on the Jucar River Basin presents a water demand of $127 \mathrm{hm}^{3} /$ year, and the water demand for irrigated agriculture reaches $990 \mathrm{hm}^{3} /$ year. The supply to urban areas comes mainly from wells and springs, but the Albacete, Sagunto and Valencia metropolitan areas use surface water. More details can be found in MAGRAMA (2013).

As shown in figure 5, comparing the total streamflows with the water demand for urban and agrarian use during an average hydrological year, we observe that consumptive uses and water resources are not synchronized in time. Water demands are concentrated in harvest months, while natural resources are slightly higher during winter and lower in summer. It is noteworthy that natural resources do not reduce dramatically in summer months because the Jucar River Basin is characterized by a strong interaction between surface water and groundwater. Because of this, the River Basin Authorities in charge of water management carry out a conjunctive use of surface and groundwater resources (Estrela et al., 2012). In recent decades, the environment has been an increasingly important issue. Therefore, sewage and wastewater treatment plants have been built and are in operation, including direct wastewater reuse after intensive treatment, increasing the water availability. 
Figure 5. Total streamflows vs. water demands during an average hydrological year (1980/2008) for the Jucar River Basin. Source of data: Jucar River Basin Authority

Using the values of total natural resources $\left(1,279 \mathrm{hm}^{3} /\right.$ year $)$ and total water demands $\left(1,117 \mathrm{hm}^{3} /\right.$ year $)$ in the Jucar Water Resources System for the 1980/81-2008/09 period, a first indicator of the water balance in the system can be derived as the ratio between both values, resulting in a value of 0.87 . This ratio represents a first approximation of the water exploitation index (WEI) as the ratio of total freshwater abstraction to total renewable resources. The closer this value is to 1 , the greater the degree of exploitation of resources is indicated. This first indicator is not sufficient because it does not take into account agrarian returns, reuse from sewage treatment stations, or any transfers that may occur in the system. Nevertheless, it reflects the high degree of exploitation suffered by this system.

The Jucar water resources system is characterized by a marked reduction in the recorded streamflows during the 1980-2009 period (Pérez-Martín et al., 2013). Figure 6 depicts the system's total natural streamflow time series, obtained by naturalization of streamflows and used in the SIMGES simulation model employed by the Water Planning Office of the Jucar River Basin Agency. As the figure shows, there has been a significant reduction in natural streamflows throughout the past 30 years, clearly showing the existence of two periods, in which the difference between their averaged streamflows is close to $500 \mathrm{hm}^{3}$ per year. This fact confirms the need to differentiate among the analysis periods 1940-2009, 1940-1979 and 1980-2009.

Figure 6. Total natural streamflow time series of the Jucar simulation model. Source of data: Jucar River Basin Authority

\subsection{Simulation model for the case study}

The first step is the construction of the simulation model for the Jucar water resources system for the current scenario. This model reflects the complex interaction among all elements in the Jucar water resources system and includes environmental requirements in order to obtain the exploitable water resources, taking into consideration the environmental objectives of the basin. To consider the current administrative concessions and operational constraints, this study draws on the SIMGES system simulation model of water resources (Andreu et al., 1996) from the DSS AQUATOOL.

Due to the special characteristics of the natural streamflows in the system, as described above, we must analyse the behaviour of the system depending on whether the simulation period covers a short period (1980-2009) or long one (1940-2009). For this reason, two multivariate ARMA stochastic models (Box and Jenkins, 1976) were calibrated using the historical data series. These models allow the generation of multiple stochastic streamflow scenarios with the same length as the historical ones. Thereby, we consider four types of streamflow time series: the naturalized streamflows during the period 1980/2008; the stochastic streamflow scenarios generated using the 1980/2008 stochastic model; the naturalized streamflows during the period 1940/2008; and the stochastic streamflow scenarios generated using the 1940/2008 stochastic model.

Based on geographical location, the exploitable water resources have been calculated at singular points in the Jucar water resources system. Figure 7 shows the scheme used to estimate the exploitable water resources, in which the detail and complexity of the system are identified. We have added to the original model five groups of demands scattered throughout the scheme, representing the strategic sites for system management. These sites correspond to the following: 
- Alarcon Reservoir, located in Jucar River headwaters

- Contreras Reservoir, located in Cabriel River headwaters, tributary of Jucar River

- Molinar Reservoir. Despite not being a regulation reservoir, by locating a group of demands in this area we intend to determine the exploitable water resources in the middle reaches of the Jucar River before the incorporation of the Cabriel River.

- Tous Reservoir, located in the middle stretch of the Jucar River.

- The Huerto Mulet gauging station. This point has been selected in order to determine the water resources availability in the lower reaches of the river.

Figure 7. Jucar water resource system model used to estimate the exploitable water resources

From the point of view of the temporal distribution of water resources availability, each set of demands is composed of two elements, representing a hypothetical agricultural supply (DA) and an urban supply (DU), considering a single $20 \%$ return for agricultural use. Agricultural demands are a lower priority than the current priorities of mixed irrigation, and urban priority coincides with the priorities of the initial urban demands.

Two reliability criteria have been selected in order to assess the water availability; these include the criteria established in the Spanish Statement of Water Planning (IPH, 2008) along with the efficiency indicators defined by Martín-Carrasco and Garrote (2007); therefore, we have analysed 8 different possible combinations of the streamflow time series, the length of the simulation period and reliability criteria.

\section{Results}

The simulation model has been used to determine the water balance in the reference scenario. Table 1 shows the balance of the flows into and out of the system in the same referenced period (1980-2008). In this balance, we can perceive the different concepts employed in the model, such as resources, demands, supplies, return flows and outflows represented by average values.

Table 1. Simplified water balance for the Jucar water resources system in the reference scenario

At this point, it would be more appropriate to refer to the results as the additional exploitable water resources because they represent the maximum demand on the system that could be supplied over the current demands, which meets the current reliability criteria required in Spanish River Basin Agencies (IPH, 2008).

Considering the geographical demand and the uncertainty of input data, a large disparity in the results can be observed. Figure 8 shows eight radial graphs representing the eight considered scenarios. Each of these graphs has 10 axes representing the new demands included in the simulation model and the calculated value of the additional exploitable water resources. The results generally show a greater availability of water resources for the long series due to the greater amount of natural resources. Moreover, the criterion used by the IPH (2008) is more demanding than the efficiency criteria because in all cases, the proceeds are greater. In addition, with the IPH 2008 criterion (IPH, 2008), the system is capable of delivering the same volume of resources in the middle and upper part of the basin, and this value increases in the lower reaches of the basin due to the high degree of exploitation in the system; however, when considering the efficiency criterion (Martín-Carrasco et al., 2007), the maximum resources are devoted to seasonal demand located at the headwaters of the Cabriel River (DA Contreras), where there are no existing demands. 
With respect to the stochastic series, the figure shows the average value of the exploitable water resources and a band representing the confidence interval for the standard deviation. Thus, the water availability is affected by the reliability criteria and the length of the simulation period, as occurs with the results obtained from the historical data series calculated by naturalized streamflows. In the stochastic scenarios analysed for the short period, the results show a higher dispersion, and the standard deviation term is higher than the average value of the exploitable water resources. These charts allow the variability in the different simulated scenarios to be visualized, improving over the initial conclusions by adding a probabilistic component that considers the dispersion of exploitable water resources, as associated with a confidence interval.

Figure 8. Location of additional exploitable water resources $\left(\mathrm{hm}^{3} /\right.$ year) obtained for the considered scenarios. In the case of the stochastic streamflow time series, the figure shows the average of exploitable water resources and a band representing the confidence interval for the standard deviation [Average - Std Dev, Average + Std Dev] [UD means Urban Demand; AD means Agrarian Demand].

\section{Discussion}

Water availability has often been used in a broad context. As stated previously, this concept can be used in different senses: as precipitation, river flows and storage of water in snow and glaciers (EEA, 2009); by employing drought indexes (Lorenzo-Lacruz et al., 2010; Pérez-Blanco and Gómez, submitted for publication); or as water yield (Lange et al., 2007; Sun et al., 2002, 2005, 2006). Furthermore, water accounts have been developed in several countries (Evaluación de Recursos Naturales, 2013; Lange et al., 2007; Masih et al., 2009; van Dijk et al., 2014), and although each country has presented its account differently, there is a general agreement on the structure and scope of water accounting (Vardon et al., 2007).

The aim of this paper is to design a scheme for determining the exploitable water resources in a Mediterranean river basin, as an indicator of water availability. Knowing the water availability in a basin will aid planners in quantifying the growth potential in the exploitation of the system. Currently, new water policies are premised on the use of DSS (Bathrellos et al., 2012). DSS is a computer tool developed to help in the process of making decisions. Such methods are essential for the purpose of providing integration, sharing visions for conflict resolution and implementing sensitivity analysis and risk assessment (Andreu et al., 1996). Because this indicator is obtained as the maximum demand that can be satisfied in the water resources system using the current inflows (conventional and un-conventional water resources, transfers, etc.), it is necessary to use a model to improve the calculation and yield good decisions.

As we have seen, there are several aspects to take into consideration. First, a water balance based on average values is not enough because it masks shortage situations due to the variability in the timing of resource inputs to the system. Therefore, it is necessary to seek a management simulation that considers the temporal variability and limitations in infrastructures and regulation. In such an analysis, a monthly step time is usually sufficient because it adequately reflects the seasonal variability of rainfall and demands. Moreover, reliability criteria can be classified into two types by the way they get the fault. In the first group, the reliability is calculated using the average results obtained for a given period, and in the second group, the reliability is determined by the worst drought event. Therefore, reliability criteria compliance is highly relevant for the system because it can serve as a reference to decide whether a new allocation can be improved or an investment is necessary. In addition, in analysing the way we obtain natural streamflows for the simulation model, we must seriously consider the use of synthetic streamflows. This analysis has a long tradition of use in hydrology for temporal and spatial streamflow simulation, having been widely used as a tool for evaluating 
water resources systems under uncertain streamflow conditions (Rajagopalan et al., 2010), adding a probabilistic component to the analysis.

Thus, the calculation of the exploitable water resources for each combination of the three determinants considered for this case study (equiprobable natural resource estimations, length of the simulation period and reliability criteria used to consider the supply satisfied) requires iterative runs of the simulation model until obtaining the maximum allocation at the selected site that meets the selected reliability criteria by employing the natural streamflow time series considered.

Considering that we have generated 200 stochastic streamflow time series, we have identified 5 points of interest to determine the exploitable water resources in the river basin, and results are calculated using two reliability criteria, this yields a total of 57,000 determinations of the exploitable water resources, as shown in table 2. To make this calculation feasible, we have used a computation algorithm programmed using spreadsheet macros, which sequentially runs the simulation management model. Even with a fully automated process, the whole process required a computation time of 480 hours, although this time has been reduced by employing 3 computers.

Table 2. Number of SIMGES model runs

This assessment has been partially analysed in recent years, yielding a significant disparity in the results due to the difference in their approaches. Some examples include the distinct methodologies employed and compiled in document Three examples on water planning (MIMAM, 2000), the White Paper on Water in Spain (MMA, 2000) and the work carried out by the Centre for Public Works Studies and Experimentation (CEDEX) (2012). Additionally, water accounts have been applied in the Jucar River Basin District. Andreu et al. (2012) reported an application of General Purpose Water Accounting (Water Accounting Standards Board, 2009) to the Jucar Water Resources System. Furthermore, the Halt-Jucar-Des project has provided an opportunity to test the feasibility of applying SEEAW for determining water accounts in the Jucar River Basin District (Evaluación de Recursos Naturales, 2013).

The White Paper on Water in Spain (MMA, 2000) obtained a first approximation of the exploitable water resources for all River Basin Districts in Spain, under specific conditions, indicating the portion of the water resources that could be exploitable in natural conditions from within the amount of water resources that could be usable by building reservoirs. An interesting result obtained from this study was the fact that, in the case of the Jucar River Basin District, the volume of manageable resources without reservoirs, channels or pumping wells represents over the $34 \%$ of natural streamflows, the biggest percentage in the Iberian Peninsula, due to the existence of aquifers hydraulically connected with rivers in the basin. Furthermore, the use of dams to regulate water resources enables the exploitation of over $75 \%$ of streamflows.

The involvement of each of the key issues analysed in this paper explains the observed differences in the results of previous works related to this case study (CEDEX, 2012; MIMAM, 2000; MMA, 2000) due to the distinct approaches such as the use of optimization models (compared with the simulation model used here), the different locations of the available resources or the use of a reliability criterion based on the worst drought event. Accordingly, the key issues proposed here summarize all of these possibilities. 


\section{Conclusions}

In this paper we have analysed the key issues for determining the exploitable water resources, as an indicator of water availability, in a Mediterranean basin where emulating the hydrological cycle in the territory is insufficient. The Jucar River Basin has been selected as case study and a calculation process has been carried out, from the general scheme presented, considering different criteria such as the origin of the streamflow time series, the length of the simulation period and the reliability criteria used to consider the demands satisfied. In view of the analyses performed, although some degree of uncertainty is always present, the results obtained show great variability. In many cases, this water resource availability is determined by hydrology, the infrastructure or the location of the current demands. It would be risky to provide a single value representing the exploitable water resources in the Jucar water resources system because, as it has been shown, the results depend crucially on the calculation methodology. Any changes in operating regulations of reservoirs and aquifers, the incorporation of new measures of wastewater reuse or resource sharing with other systems would require a new resource assessment and, consequently, yield different values of the exploitable water resources.

New water policies in the European Union are demanding more standardized management of water resources. Even so, the obtained results do not correspond exactly to those recommended by SEEAW (UNSD, 2012). Overall, a preliminary analysis of the key issues is important in the calculation of the exploitable water resources because as shown here, these preconditions will largely determine the results. In this sense, even the Blueprint to safeguard Europe's resources (EC, 2012) recognises that the aquatic environments differ greatly across the EU and therefore does not propose a one-size-fits-all solution, in line with the principle of subsidiarity. It is necessary that policymakers and stakeholders make a decision about the methodology used to determine the water availability in a river basin. It is noteworthy that, in Spain, a large part of these methodological decisions (reliability criteria, natural streamflows time series, simulation models, etc.) are included in the Spanish Statement of Water Planning (IPH, 2008) with normative status guaranteeing consistency and comparability of the results.

\section{Acknowledgements}

The authors wish to thank the Confederación Hidrográfica del Júcar (Spanish Ministry of the Environment) for the data provided in developing this study and the Spanish Ministry of Economy and Competitiveness for its financial support through the projects SCARCE (Consolider-Ingenio 2010 CSD2009-00065) and NUTEGES (CGL2012-34978). We also value the support provided by the European Community's Seventh Framework Program in financing the projects DROUGHT-R\&SPI (FP7-ENV-2011, 282769), ENHANCE (FP7-ENV-2012, 308438), WAMCD (EC-DG Environment No. 07.0329/2013/671291/SUB/ENV.C.1) and LIFE ALBUFERA (LIFE12 ENV/ES/000685).

\section{References}

Andreu J, Capilla J, Sanchis E. AQUATOOL, a generalized decision-support system for water resources planning and operational management. J. Hydrol 1996; 177: 269-291. Doi: 10.1016/0022-1694(95)02963-X

Andreu J, Momblanch A, Paredes J, Pérez MA, Solera A. Potencial role of standarization water accounting in Spanish basins. Water accounting. International Approaches to Policy and Decision-making. 2012, pp. 123-138.

Asefa T, Clayton J, Adams A, Anderson D. Performance evaluation of a water resource system under varying climatic conditions: Reliability, Resilence, Vulnerability and beyond. J. Hydrol 2014; 508: 53-65. 
Bangash RF, Passuello A, Hammond M, Schuhmacher M. Water allocation assessment in low flow river under data scarce conditions: A study of hydrological simulation in Mediterranean basin. Science of the Total Environment 2012; 440: 60-71. http://dx.doi.org/10.1016/i.scitotenv.2012.08.031

Bathrellos GD, Gaki-Papanastassiou K, Skilodimou HD, Papanastassiou D and Chousianitis KG. Potential suitability for urban planning and industry development using natural hazard maps and geologicalgeomorphological parameters. Environ Earth Sci (2012) 66 (2): 537-548

Box GEP and Jenkins G. Time series analysis, forecasting and control. Revised edition, Holden-Day Inc., San Francisco, 1976.

CEDEX. Efecto del cambio climático en los recursos hídricos disponibles en los sistemas de explotación. Centro de Estudios y Experimentación de Obras Públicas. Ministerio de Agricultura, Alimentación y Medio Ambiente. Madrid, 2012.

Chavez-Jimenez A, Lama B, Garrote L, Martin-Carrasco F, Sordo-Ward A, Mediero L. Characterisation of the Sensitivity of Water Resources Systems to Climate Change. Water Resour Manage 2013; 27: 4237-4258. Doi: 10.1007/s11269-013-0404-2

Delgado J, Llorens P, Nord G, Calder IR, Gallart F. Modelling the hydrological response of a Mediterranean medium-sized headwater basin subject to land cover change: the Cardener River basin (NE Spain). J Hydrol 2010; 383: 125-34.

EEA. Water resources across Europe - confronting water scarcity and drought (Report No. 2/2009). European Environment Agency, Copenhagen (Denmark), 2009.

Estrela T, Pérez-Martin MA and Vargas E. Impacts of climate change on water resources in Spain, Hydrological Sciences Journal 2012; DOI: 10.1080/02626667.2012.702213

Estrela T and Vargas E. Drought Management Plans in the European Union. The case of Spain. Water Resour Manage, 2012, 26, pp. 1537-1553.

European Commission. Communication to the European Parliament and the Council - Blueprint to safeguard Europe's water resources, COM/2012/673 final. Brussels, 2012.

Evaluación de Recursos Naturales. Halting Desertification in the Jucar River Basin. HALT-JÚCAR-DES Final Report. Valencia, 2013.

Ferrer J, Pérez-Martín MA, Jiménez S, Estrela T, Andreu J. GIS-based models for water quantity and quality assessment in the Júcar River Basin, Spain, including climate change effects. Science of the Total Environment 2012; 440: 42-59 http://dx.doi.org/10.1016/j.scitotenv.2012.08.032

Hashimoto T, Stedinger JR, Loucks DP. Reliability, resiliency, and vulnerability criteria for water resources system performance evaluation. Water Resour. Res. 1982; 18: 14-20

IPH - Instrucción de Planificación Hidrológica. Ministerio de Medio Ambiente, y Medio Rural y Marino.- 15340 ORDEN ARM/2656/2008, de 10 de septiembre. Boletín Oficial del Estado 229, 38472-38582. 
Lange G-M, Mungatana E, Hassan R. Water accounting for the Orange River Basin: An economic perspective on managing a transboundary resource. Ecological Economics 2007; 61: 660-670 DOI: 10.1016/j.ecolecon.2006.07.032

Lorenzo-Lacruz J, Vicente-Serrano SM, López-Moreno JI, Beguería S, García-Ruiz JM, Cuadrat JM. The impact of droughts and water management on various hydrological systems in the headwaters of the Tagus River (central Spain). J. Hydrol 2010; 386: 13-26. doi:10.1016/j.jhydrol.2010.01.001

Loucks DP and van Beek E. Water Resources Systems Planning and Management. An Introduction to Methods, Models and Applications. Studies and Reports in Hydrology. ISBN 92-3-103998-9. Paris, 2005.

Lu N, Sun G, Feng X, Fu B. Water yield responses to climate change and variability across the North-South Transect of Eastern China (NSTEC). J. Hydrol 2013; 481: 96-105. http://dx.doi.org/10.1016/j.jhydrol.2012.12.020

MAGRAMA. Memoria-Anejo 6. Sistemas de Explotación y Balances. Demarcación Hidrográfica del Júcar. Ministerio de Agricultura, Alimentación y Medio Ambiente. Valencia, 2013.

Marco J. Hidrología estocástica y planeamiento hidráulico. Conceptos y métodos para la planificación hidrológica. CIMNE. Barcelona, 1993, pp. 97-105.

Martín-Carrasco F and Garrote L. Drought-induced water scarcity in water resources systems. In: Vasiliev OF, van Gelder PHAJM, Plate EJ, Bolgov MV (eds), Extreme Hydrological Events: New Concepts for Security-ISBN 978- 14020-5739-7. NATO Science Series, 2007; vol. 78, Part 4. pp. 301-311. doi:10.1007/978-1-4020-5741-0_2. Russia, pp. 301-311

Masih I, Ahmad M, Uhlenbrook S, Turral H, Karimi P. Analysing streamflow variability and water allocation for sustainable management of water resources in the semi-arid Karkheh river basin, Iran. Physics and Chemistry of the Earth, 2009; 34: 329-340. Doi: 10.1016/j.pce.2008.09.006

MIMAM. Tres casos de Planificación Hidrológica. Ministerio de Medio Ambiente. Madrid, 2000.

MMA. White Paper on Water in Spain. Centro de publicaciones del Ministerio de Medio Ambiente, Madrid, 2000.

Molle F, Mamanpoush A, Miranzadeh M. Robbing Yadullah's water to irrigate Saeid's garden: Hydrology and water rights in a village of central Iran. Research Report 80. Colombo, Sri Lanka: International Water Management Institute, 2004.

Pérez-Blanco CD and Gómez CM. Drought management plans and water availability in agriculture. A risk assessment model for a Southern European Basin, Weather and Climate Extremes, submitted for publication. http://dx.doi.org/10.1016/j.wace.2014.02.003

Pérez-Martín MA, Thurston W, Estrela T, del Amo P. Cambio en las series hidrológicas de los últimos 30 años y sus causas. El efecto 80. III Jornadas de Ingeniería del Agua (JIA 2013). La protección contra los riesgos hídricos. Vol 1, 527:534. Valencia, 2013. 
Pulido-Velázquez D, Garrote L, Andreu J, Martin-Carrasco FJ, Iglesias A. A methodology to diagnose the effect of climate change and to identify adaptive strategies to reduce its impacts in conjunctive-use systems at basin scale. J. Hydrol 2011; 405: 110-122. doi:10.1016/j.jhydrol.2011.05.014

Rajagopalan B, Salas J, Lall U. Stochastic methods for modeling precipitation and streamflow. In: Advances in data-based approaches for hydrologic modeling and forecasting, 2010; pp. 17-52.

Rani D, Moreira M. A survey and potential application in reservoir systems operation. Water Resources Management, 2010; 24 (6): 1107-1138.

Solera A, Paredes-Arquiola J, Andreu J. Componentes de un sistema de recursos hidráulicos. Modelos de uso conjunto de aguas superficiales y subterráneas. Instituto Geológico y Minero de España. Madrid, 2010a, pp. 111141. ISBN 978-84-7840-852-8.

Solera A, Paredes-Arquiola J, Andreu J. Datos hidrológicos. Modelos de uso conjunto de aguas superficiales y subterráneas. Instituto Geológico y Minero de España. Madrid, 2010b, pp. 111-141. ISBN 978-84-7840-852-8.

Sulis A and Sechi GM. Comparison of generic simulation models for water resource systems. Environmental Modelling \& Software, 2013; 40: 214-225. http://dx.doi.org/10.1016/i.envsoft.2012.09.012

Sun G, McNulty SG, Moore JM, Bunch C, Ni J. Potential impacts of climate change on rainfall erosivity and water availability in China in the next 100 Years. In: The Proceedings of the $12^{\text {th }}$ International Soil Conservation Conference, Beijing China, May 2002.

Sun G, McNulty SG, Lu J, Amatya DM, Liang Y, Kolka RK. Regional annual water yield from forest lands and its response to potential deforestation across the southeastern United States. J. Hydrol. 2005; 308: 258-268.

Sun G, Zhou G, Zhang Z, Wei W, McNulty SG, Vose JM. Potential water yield reduction due to forestation across China. J. Hydrol. 2006; 328: 548-558. doi:10.1016/j.jhydrol.2005.12.013

United Nations Statistics Division (UNSD). System of Environmental-Economic Accounting for Water. Available at http://unstats.un.org/unsd/envaccounting/water.asp New York, 2012.

van Dijk A, Mount R, Gibbons P, Vardon M, Canadell P. Environmental reporting and accounting in Australia: Progress, prospect and research priorities. Science of the Total Environment 2014; Vols. 473-474: 338-349.

Vardon M, Lenzen M, Peevor S, Creaser M. Water accounting in Australia. Ecological Economics 2007; 61: 650659. DOI: 10.1016/j.ecolecon.2006.07.033

Vargas-Amelin E and Pindado P. The challenge of climate change in Spain: Water resources, agriculture and land. J. Hydrol. 2013. http://dx.doi.org/10.1016/i.jhydrol.2013.11.035

Water Accounting Standards Board. Preliminary Australian Water Accounting Standard and Associated Model Report, Australia: Commonwealth of Australia, 2009. 